\title{
Ironia, tragizm i tajemnica Boga w dramacie biblijnym Jephtes George'a Buchanana - Jana Zawickiego
}

Historię Jeftego, zawartą w jedenastym rozdziale Księgi Sędziów, podjął w 1554 r. szkocki poeta George Buchanan w tragedii zatytułowanej Iephthes sive votum. Na gruncie humanizmu chrześcijańskiego dzieło to było pierwszą udaną próbą przedstawienia motywu biblijnego w schemacie konstrukcyjnym tragedii greckiej ${ }^{1}$, próbą, której podjęcie poprzedziło odkrycie wewnętrznego związku między Biblią a antykiem, m.in. w odniesieniu do tak podstawowego problemu, jak relacja wolnej woli człowieka do siły wyższej, transcendentalnej. Już podtytuł dramatu (votum) wskazywał na istotę konfliktu tragicznego tkwiącego w pochopnym ślubie złożonym przez głównego bohatera.

Przywódca Galaadczyków, Jefte, obiecał, że złoży Bogu w ofierze dziękczynnej za zwycięstwo nad Ammonitami tego, kto jako pierwszy wyjdzie mu na spotkanie. Osobą tą okazała się jego jedyna córka. Jej imienia Księga Sędziów nie podaje, wspomina natomiast o heroicznej decyzji dziewczyny o poświęceniu własnego życia, powierzonego zrozpaczonemu ojcu (Sdz 11, 30-36). W dramacie Buchanana wątek biblijny znalazł dopełnienie w analogicznym motywie ofiary zawartym $\mathrm{w}$ tragedii Eurypidesa Ifigenia w Aulidzie. Łacińskie dzieło szkockiego humanisty przeszczepił na grunt literatury polskiej Jan Zawicki w utworze Jeftes z 1587 r. ${ }^{2}$ Mimo różnicy czasowej i wyznaniowej dzielącej oba

1 Por. J. Abramowska, Ead i fortuna. O tragedii renesansowej w Polsce, Ossolineum, Wrocław 1974, s. 62.

2 Twórczość szkockiego humanisty znana była już wcześniej, o czym świadczy Psatterz Dawidowy Jana Kochanowskiego. Por. E. Buszewicz, George Buchanan a twórczość 
teksty (tragedia Buchanana — kryptoprotestanta — wyprzedzała o prawie pół wieku wersję Zawickiego, jednego z katolickich pisarzy z kręgu Jana Zamoyskiego) ${ }^{3}$, polski Jeftes zachował główny zrąb semantyczny pierwowzoru, czyli dramat człowieka religijnego wynikający z usytuowania wobec najważniejszego kontrpartnera - Boga.

Warto przypomnieć, że niejednoznaczność opowieści biblijnej, połączona z jej ambiwalentną egzegezą dokonywaną w pierwszych wiekach chrześcijaństwa i średniowieczu ${ }^{4}$ miała się wyrazić i później, w okresie nasilonych sporów wyznaniowych XVI w. ${ }^{5}$, a zagadkowy wymiar nieroztropnego czynu Jeftego, obok równie tajemniczego i dwuznacznego milczenia Boga, umożliwiał wyprowadzenie biegunowo skrajnych

Jana Kochanowskiego, w: Twórczość Jana Kochanowskiego w kontekście nowotacinskiej literatury europejskiej i polskiej, red. G. Urban-Godziek, Kraków 2010, s. 118-128.

3 Abramowska (por. Ead., op. cit., s. 78) wspomina o etapie kryptokalwinizmu w kształtowaniu się tożsamości wyznaniowej poety, który dopiero w latach sześćdziesiątych przystał oficjalnie do Kościoła reformowanego. Pewną analogię miałby stanowić przykład Mikołaja Reja, o którym w latach czterdziestych mówiono jako o „kryptokalwinie”. Zob. J. Maciuszko, Mikotaj Rej. Zapomniany teolog ewangelicki z XVI w., ChAT, Warszawa 2002, np. s. 78-79.

4 Zob. m.in. Św. Augustyn, Problemy Heptateuchu, cz. 2, ATK, Warszawa 1990 („Pisma Starochrześcijańskich Pisarzy”, t. XLVII), s. 105-120; Orygenes, Homilie o Księgach Liczb, Jozuego, Sędziów, przeł. i oprac. S. Kalinowski, ATK, Warszawa 1986 („Pisma Starochrześcijańskich Pisarzy”, t. XXXIV), s. 235-243; Id., Komentarz do Ewangelii św. Jana, przeł. S. Kalinowski, WAM, Kraków 2003, s. 210 (ks. VI, (277) (278)); Św. Jan Chryzostom, Mowy przeciwko judaizantom i Żydom, przeciwko Żydom i Hellenom, przeł. i oprac. J. Iluk, WAM, Kraków 2007, s. 102; Św. Cyryl Jerozolimski, Katechezy, przeł. W. Kania, wstęp J. S. Bojarski, oprac. M. A. Bogucki, ATK, Warszawa 1973 („Pisma Starochrześcijańskich Pisarzy”, t. IX), s. 256; Św. Metody z Olimpu, Mowa X (strofa XIII hymnu Tekli), w: Id., Uczta, przeł. S. Kalinkowski, wstęp i oprac. E. Stanula, ATK, Warszawa 1973 („Pisma Starochrześcijańskich Pisarzy”, t. IX), s. 103; Józef Flawiusz, Dzieje dawnego Izraela, przeł. Z. Kubiak, J. Radożycki, wstęp E. Dąbrowski, W. Malej, RYTM, Warszawa 2001, ks. V, rozdz. III, 10 (266); zob. komentarz Mikołaja z Liry do Księgi Sędziów w: Biblia Sacra cum Glossis, Interlineari et Ordinaria, Nicolai Lyrani Postilla et Moralitatibus, Burgensis Additionibus, et Thonigni Replicis, Gaspard Trechsel, Lugduni 1545, s. 47. O egzegezach żydowskich komentatorów por. D. Abecassis, Jephthah's Daughter in the Jewish Egzegetical Tradition, McGill University, Montreal 1993.

5 Zob. A. Linton, Sacrificed or Spared? The Fate of Jephthah's Daughter in Early Modern Theological and Literary Texts, „German Life and Letters”, 57: 3, July 2004 , s. 237-255; J. Abramowska, op. cit., s. 62-63. 
wniosków natury antropologicznej i teologicznej ${ }^{6}$. Przypominano więc sobie pytania zadawane niegdyś przez Tertuliana: „Unde malum?” oraz św. Augustyna: „Unde malum faciamus?” i udzielano na nie konkretnych odpowiedzi, które za zbrodniczą ofiarę winiły na przemian: Boga lub człowieka. Teandryczny wymiar dramatu wtłoczonego w niespełna dziesięć biblijnych wersetów ( $\mathrm{Sdz} 11,30-40)$ niósł też ze sobą znaczny potencjał tragiczny i skłaniał do wyrażania najrozmaitszych wątpliwości.

Problem zła próbowała również na swój sposób wyjaśnić tragedia antyczna, opisując zło za pomocą kategorii tragizmu. Mimo iż mit biblijny $^{7}$ ewokował optymistyczną wizję świata ${ }^{8}$, to jednak historia Jeftego zajmowała na kartach Pisma Świętego miejsce szczególne. Nasuwała bowiem myśl o fenomenie istnienia ciemnych szczelin na obrzeżach religijnego systemu i niebezpiecznym zbliżaniu się Biblii do mitu tragicznego głównie w ujęciach takich istotnych kwestii, jak: relacja Boga i człowieka, pojęcie winy, kary, losu czy istoty zła.

Typowe dla tragedii antycznej pojęcie Boga nie znalazło odbicia w Biblii. Punktów wspólnych należało szukać w koncepcji religii jako obszaru jednostkowego rozrachunku z Jahwe. Tylko tu homo religiosus mógł otwierać się na promienie bożego objawienia lub pozostawać w mrokach błędu, ale wówczas był to tragizm jego osobistej relacji z Bogiem. Toteż myśl, że biblijny Jefte przelał krew własnego dziecka ze względu na błędne pojmowanie woli Boga, znajduje tu swoje uza-

6 O interpretacji ślubowania Jeftego por. D. Marcus, Jephthah and his vow, Texas Tech UP, Texas 1986. Zob. także: J. L. Thompson, Writing the Wrongs: Women of the Old Testament among Biblical Commentators from Philo through the Reformation, Oxford UP, Oxford 2001; S. Grzybek, Starotestamentowe ofiary w ludziach a ślub Jeftego, „Ruch Biblijny i Liturgiczny”, 1956, 9, s. 9-23; E. W. Bullinger, Did Jephthah Really Sacrifice his Daughter? An Analysis of Judges 11:31, w: Id., Great Cloud of Witnesses in Hebrews 11, Kregel Publications, Grand Rapids 1979, s. 324-331; I. Mehlman, Jephthah and Jephthah's Daughter, „World Jewish Bible Society”, 1962, s. 21-23.

Zob. m.in. P. Ricoeur, Funkcja symboliczna mitu, „Znak”, 1968, 20, s. 1253-1260; M. Eliade, Traktat o historii religii, przeł. J. Wierusz-Kowalski, wstęp L. Kołakowski, posł. opatrzył S. Tokarski, OPUS, Łódź 1993; Id., Sacrum, mit, historia. Wybór esejów, wybór M. Czerwiński, wstęp B. Moliński, przeł. A. Tatarkiewicz, PIW, Warszawa 1970; F. V. Manning, Biblia — dogmat, mit czy tajemnica, „Studia Theologia Varsoviensia”, 1977, 15, nr 1, s. 21-100; K. Hoła, Obecność i rola mitów w Piśmie Świętym, „Znak”, 1977, 29, s. 913-923.

8 Szerzej o tym por. M. Czajkowski, Egzystencjalna lektura Biblii, KUL, Lublin 1993, s. 74. 
sadnienie. W jakiś sposób potwierdzają to także i dramat Buchanana, i wersja Zawickiego: oto Jefte poprzez własny upór sprowadza nieszczęście na swój dom.

Pytanie o sacrum w kontekście tego, co spotkało Jeftego, nie zanika zupełnie w dziele Buchanana i powraca nawet wtedy, gdy Bóg zdaje się wyłączony z odpowiedzialności za realizację ślubu Jeftego. Właśnie tu mogła pojawić się myśl o nieszczęściu wynikającym nie tylko z przypadkowej koincydencji zdarzeń, nierespektowania zasad etyki ludzkiej albo Bożego Prawa. A stąd już niedaleka droga do uzupełnienia Biblii o mit tragiczny i ukazania dwóch różnych wizji Boga, w których, obok teodycei, mogło pojawić się także Jego oskarżenie 9 . Niejednoznaczne ujęcie boskości stwarzałoby wówczas możliwość zaistnienia paradoksu w sferze ludzkiej egzystencji, paradoksu określającego status Jeftego jako „niewinnego grzesznika” ${ }^{10}$.

Lekturze dzieła towarzyszy wszak wrażenie — spotęgowane przez analogię do dziejów Edypa - jakby intencje i czyny Jeftego zostały w sposób ironiczny skonfrontowane z ich skutkami, jakby „wolna wola bohatera stykała się z nieuchronnym losem" ${ }^{11}$. Poza tym, wrażenie to wzmacnia świadomość obecności w przestrzeni dramatu więcej niż jednego planu przyczynowego, chociaż bohaterowie nie są w stanie zrozumieć, w jaki sposób przenikają się: plan bożych wyroków (ujawnionych w Prologu) i plan ludzkiej egzystencji bohaterów. Nieszczęście Jeftego — rozgrywające się w cieniu tajemniczego milczenia Jahwe — wymyka się próbie jednoznacznej interpretacji. Mimo że w wykreowanej przez Buchanana tragedii Bóg-los ustępuje z pewnością miejsca Bogu przychodzącemu ze światłem swego objawienia, to jednak odnaleźć można w dziele miejsca niejasne, w których fenomen sacrum ulega chwilami niejednoznacznej waloryzacji.

Już w Prologu wygłoszonym przez Anioła znajdujemy ponurą wizję nieszczęścia Jeftego:

9 Zob. Bóg i zto. Pisma Bazylego Wielkiego, Grzegorza z Nyssy i Jana Chryzostoma, wstęp, przypisy i przewodnik tematyczny M. Congourdeau, teksty greckie przeł. K. Kochańczyk, J. Naumowicz, M. Przyszychowska, oprac. J. Naumowicz, WAM, Kraków 2003 („Biblioteka Ojców Kościoła”, nr 23).

10 Zob. J. Abramowska, op. cit., s. 61-89.

11 W. Szturc, „Król Edyp” Sofoklesa. Ironia tragiczna jako zasada budowy akcji tragedii, w: Id., Osiem szkiców o ironii, Universitas, Kraków 1994, s. 9. 
A Jeftes by nie wpyśniał, mieszkając w pokoju,

Wnet szwank podejmie w domu żałosny z frasunkiem,

Bo to straci, co ma mieć w starości ratunkiem:

Iż dla skutku szczęśliwej wojny to ślubował,

Że co mi drogę zajdzie, będę ofiarował

Bogu ofiarę krwawą.

$$
\text { (w. 61-66) })^{12}
$$

Wprawdzie mieści się ono w uniwersalnym planie Bożej dydaktyki ${ }^{13}$ mającej skruszyć „hardą pychę” (w. 36) „zaślepionych od szczęścia” (w. 35), jednak w perspektywie całego utworu nie sposób trafić na ślad podobnego afektu ze strony Jeftego. Paradoksalnie jest on mężem charakteryzującym się niezachwianą pobożnością i bezgranicznym zaufaniem w boską Opatrzność. Z relacji posła opisującego triumf Jeftego nad Ammonitami wyłania się sylwetka nie tylko dzielnego i charyzmatycznego wojownika oddanego bez reszty Bogu i uzależniającego swoje zwycięstwo od ingerencji Najwyższego, lecz także sprawiedliwego i roztropnego wodza usiłującego w bezkrwawy sposób zakończyć konflikt. Dziękczynny hymn Jeftego po skończonej bitwie jest głębokim wyznaniem wiary $\mathrm{w}$ opatrznościowe aksjomaty Boga, połączonym z jednoczesną skruchą i wyznaniem zbiorowego grzechu apostazji. W zestawieniu ze słowami Anioła z Prologu omawiana wypowiedź Jeftego nabiera jednak charakteru gorzkiej ironii:

Sprawco okrągłej ziemie, Boże prawy,

Sam sprawiedliwy, sam dobrym łaskawy,

Złośliwym srogi, skromnym miłościwy,

A nad niezbożnym sprawiedliwie mściwy!

Chociaż Cię często do gniewu wiedziemy

12 J. Zawicki, Jeftes, w: Dramaty biblijne XVI wieku, oprac., wstęp i przypisy K. Wilczewska, Towarzystwo Naukowe KUL, Lublin 2000 („Staropolski dramat religijny”, t. V). Wszystkie cytaty z dzieła Zawickiego pochodzą z tej edycji.

13 Zob. np. Am 6, 8: „Brzydzę się ia pychą Jakobową, a domów iego nienawidzę y wydam miasto z obywatelmi iego". Wszystkie cytaty biblijne w języku polskim podaję za: Biblia to jest Księgi Starego y Nowego Przymierza wedtug Eacińskiego przektadu starego, w kościele powszechnym przyjętego, na Polski ięzyk z nowu z pilnościa przetożone, [...] przez D. Iakuba Wuyka z Wagrowca, Theologa Societatis Iesu, Drukarnia Łazarzowa, Kraków 1599, s. 972. 
Złościami swemi, przedsię Cię możemy

Ubłagać. A Ty łaskawe Twe oko

Przeciw nam, Panie, wynosisz wysoko.

Dość nas cisnęło tyrańskie karanie

Słuszne za złości naszych przedłużanie

I niepobożnym daliśmy, złośliwi,

Karanie z siebie.

(w. 388-399)

Nakładając na siebie te dwa fakty, należałoby uznać istnienie następującej logiki stojącej w sprzeczności ze słowami anielskimi: Jefte jest pobożny, dlatego zostanie ukarany przez Boga. Buchanan i Zawicki dodatkowo intensyfikują siłę oddziaływania tragicznej ironii poprzez umiejscowienie ślubu Jeftego nie przed decydującą bitwą, jak jest w Biblii, lecz w momencie bezpośrednio po niej następującym. Jefte kończy dziękczynną modlitwę w ten sposób:

Nie przepominaj przymierza Twojego

A przyjmi wdzięcznie ślub od sługi Twego,

Ślub, chociaż lichy; Pańskie oczy Twoje

Niechaj uznają chętne dary moje.

$$
\text { (w. 444-447) }
$$

Taka perspektywa znacznie osłabia rangę „winy” Jeftego w stosunku do przekazu Księgi Sędziów. Wypowiedziane w trybie warunkowym biblijne zdanie: "Si tradideris filios Ammon in manus meas: $\mathrm{Quicumque} \mathrm{primus} \mathrm{fueris} \mathrm{egressus} \mathrm{de} \mathrm{foribus} \mathrm{domus} \mathrm{meae,} \mathrm{mihique}$ occurrerit revertenti cum pace a filiis Ammon, eum holocaustum offeram Domino" (Sdz 11, 30) ${ }^{14}$ różni się od przytaczanego wyżej passusu, w którym Jefte patrzy na przyszłą ofiarę jak na dar wdzięcznego serca.

$\mathrm{O}$ wiele bardziej niepokojąca jest jednak subtelna różnica widoczna w sposobie precyzowania przedmiotu ofiary. Podczas gdy Biblia zawęża

14 Cyt. za: Biblia. R. Stephanus Lectori. En tibi Biblior vulgata editio, in qua iuxta Hebraicorum versuum rationem singula capita versibus distincta sunt, [...], Robert Stephanus, Geneva 1555, k. 70. W Biblii Jakuba Wujka czytamy w tym miejscu: „Jeśli dasz syny Ammon w ręce moie: Ktokolwiek pierwszy wynidzie ze drzwi domu mego a zabieży mi wracaiącemu się w pokoju od synów Ammon, tego ofiaruję całopalenie Panu” (s. 254). 
go raczej do ludzkiego życia („Quicumque primus fuerit egressus de foribus domus meae”; „K tokolwiek pierwszy wynidzie ze drzwi domu mego", Sdz 11,31), to zarówno tragedia łacińska, jak i polska parafraza ujmują go w kategoriach szerszych („, o mi wprzód zajdzie drógę”, w. 448; „Qu od primum ad aedes sospiti occurret meas”, w. 484), zastępując zaimek 'kto' bardziej uniwersalnym „co” lub „cokolwiek”.

Jakie ma to znaczenie dla wymowy tragedii? W perspektywie porównawczej obu tych tradycji jest to znowu sygnał osłabienia rangi winy Jeftego w dramacie Buchanana - Zawickiego wobec pierwowzoru biblijnego, w którym bohater, składając ślub, myślał o człowieku. Istotniejsze wydaje się jednak funkcjonowanie zaimka „co”/,cokolwiek” wewnątrz samych dramatów. Podczas gdy Anioł już w Prologu łączy ślub z jego strasznymi konsekwencjami, Jefte — jak na ironię — obiecując złożyć w ofierze nie „kogos”, lecz „coš” (!), zupełnie nie przewiduje tragicznych następstw swego postępowania. Z drugiej strony Jeftemu $\mathrm{z}$ dramatu - $\mathrm{w}$ przeciwieństwie do bohatera biblijnego — nie można zarzucić nieznajomości bożego zamysłu odnoszącego się do rytu ofiarniczego. W bożej semantyce ofiara miała być aktem miłości i dziękczynienia, a nie przemocy czy handlu ${ }^{15}$.

Wygląda na to, że renesansowy Jefte zna znaczenie tych praktyk i dlatego w jego ślubie akcent nie pada ani na kontrakt, ani na ofiarę z człowieka. Obietnicę (w. 444-447) poprzedza pochwałą Stwórcy za cuda dokonane wśród ludu Izraela (w. 424-443). W podobieństwach anielskiego proroctwa z Prologu do nieszczęsnego ślubowania Jeftego Debora Kuller Shuger dostrzega ponurą ironię łączącą się z równie ponurą ewentualnością, że „ta sama siła, która karze Jeftego za ślub, jednocześnie ślub ten warunkuje" ${ }^{16}$. Takie ujęcie niewątpliwie zbliżałoby analizowany dramat do teologicznego jądra tragedii greckiej i przywoływało na myśl kalwinową naukę o predestynacji. Należy jednak zaznaczyć, że w okresie, w którym Buchanan pisał tragedię, doktryna ta nie była jeszcze w pełni ukształtowana.

15 Por. L. R. Klein, The Triumph of Irony in the Book Judges, Almond, Sheffield 1988, s. 91.

16 D. Kuller Shuger, The Renaissance Bible. Scholarship, Sacrifice, and Subjectivity, University of California Press, Berkeley 1994, s. 139. Jeśli nie zaznaczono inaczej, wszystkie przekłady tekstów obcojęzycznych pochodzą od autora artykułu [T. L.]. Zob. D. Stone, French Humanist Tragedy: A Reassessment, Manchester UP, Manchester 1974, s. 111. 
Zestawienie słów Anioła z nieświadomą ich realizacją przez Jeftego daje prawo do wypowiedzenia sądu o głęboko tragicznej sytuacji bohatera, co nie powinno dziwić zważywszy już na kwalifikacje gatunkową dzieła Buchanana - Zawickiego, określonego jako „tragedia biblijna”. Tymczasem jednak podobnego sformułowania można użyć wobec opowiadania z Księgi Sędziów, które na gruncie teologii i antropologii judeochrześcijańskiej przybiera postać paradoksu, swoistej herezji.

Radykalni krytycy, negujący możliwość istnienia tragedii biblijnej, przytaczają apologetyczny argument o bożym miłosierdziu i racjonalności, mówiąc, że gdzie jest miłosierdzie i racjonalność, tam nie ma tragedii ${ }^{17}$. Spośród innych argumentów wymieniają nowotestamentowy optymizm Zmartwychwstania oraz genezyjskie przeświadczenie o istnieniu w Biblii wyraźnej granicy oddzielającej dobro i zło (Rdz 1, 3-5). Ich zdaniem, skoro Pismo Święte odrzuca relatywizm w dziedzinie aksjologii — a ten właściwy jest tragedii — to Biblia nie może mieć wydźwięku tragicznego ${ }^{18}$. Co ciekawe, także w tragedii greckiej istnieje tendencja zmierzająca w kierunku teodycei, odcięcia bogów od ludzkiego nieszczęścia poprzez tworzenie istotowej zależności pomiędzy winą człowieka a zasłużonym cierpieniem będącym przejawem boskiego wymiaru sprawiedliwości (Ajschylos, Oresteja).

A jednak biblijna historia o Jeftem sprawia wrażenie, jakoby w obrębie eudajmonicznego mitu biblijnego znajdowały się miejsca zacienione, w których Boże aksjomaty zostają na pewien czas zawieszone. Co prawda „Stary Testament nie odróżniał wyraźnie woli Bożej od dopustu Bożego i przypisywał Bogu — jako Przyczynie Pierwszej — także wszelkie zło, dotykające człowieka, jak choroby, pokusy itp."19 (np. prorok

17 Por. G. Steiner, The Death of Tragedy, Oxford UP, New York 1980, s. 4.

18 Por. B. Kurzweil, Job and the Possibility of Biblical Tragedy, w: Arguments and Doctrines, ed. A. A. Cohen, Jewish Publication Society, Philadelphia 1970, s. 338. Zob. M. Kocur, Tragedia jako objawienie. Geneza tragiczności chrześcijańskiej, w: Kultura i tragiczność, red. K. Łukasiewicz, D. Wolska, Wydawnictwo Uniwersytetu Wrocławskiego, Wrocław 2007; R. Niebuchr, Poza tragizmem. Eseje o chrześcijańskiej interpretacji historii, Znak, Kraków 1985; Ch. Saint-Evremond, O tragedii starożytnej i nowoczesnej, w: Id., O sztuce życia i życiu sztuki. Eseje, listy, maksymy, wybrał, przeł., wstęp R. Brandwajn, Czytelnik, Warszawa 1962; I. Sławińska, Dramat religijny: jego wyróżniki i paradygmaty, w: Ead., Odczytywanie dramatu, PWN, Warszawa 1988, s. 66-92.

19 M. Peter, Wyktad Pisma Świętego Starego Testamentu, Pallottinum, Poznań 2005, s. 77. 
Amos (Am 3, 6b) obwieszczał: „Aza będzie złe w mieście, któregoby Pan nie uczynił?”, a Izajasz (Iz 45, 7) oznajmiał następujące słowa Pana: „Ja Pan, a niemasz innego, tworzący światłość y tworzący ciemności, czyniący pokóy y stwarzający złość”, Hiob zaś (Hi 2, 10) tak odpowiadał rozpaczającej małżonce: „Jeśliśmy przyięli dobra z ręki Bożey, złego czemubyśmy przyiymować nie mieli?’). Okazuje się jednak, że teza traktująca o ostatecznej delimitacji dobra i zła na płaszczyźnie biblijnej powinna zostać ponownie przedyskutowana w kontekście opowiadania o Jeftem. Jak widać na przykładzie Saula, granica pomiędzy tymi wartościami nie jest już tak jednoznaczna.

Zdaniem J. Cheryla Exuma, w Biblii „zależność dobra i zła dostrzegana w kontekście Bożej działalności, daje początek tragicznej świadomości”20. W takim kontekście Saul mógłby zasługiwać na miano bohatera tragicznego ${ }^{21}$. Bóg najpierw wynosi Saula na wyżyny władzy, a następnie z niezrozumiałych dlań powodów odwraca się od niego, nękając go wrogim Duchem, czym doprowadza swego pomazańca do obłędu. Analogia do historii Jeftego jest wyraźna także poprzez mniemanie o istnieniu jakiejś „złośliwej transcendencji” czy „arbitralnego losu” („hostile transcendence”, „arbitrary fate”) ${ }^{22}$. Znamienne, że dramat nie jest pozbawiony pewnych symptomów fatum: obwieszczenie Boskich wyroków względem Jeftego, akt tragicznej obietnicy (chociaż Jefte nie miał na myśli ofiary z człowieka) i uporczywe trwanie przy niej aż do ostatecznego wypełnienia.

Motyw praedestinatio pojawiający się w pewnych fragmentach tragedii zyskuje dodatkową perspektywę interpretacyjną w konfrontacji z tym passusem z Księgi Sędziów, który informuje o Duchu Bożym spoczywającym nad Jeftem. Widać przy tym wyraźnie, że, gdyby Jefte ślubował z premedytacją, potencjał tragiczny uległby znacznemu osłabieniu. Do jego wzmocnienia potrzebna była ingerencja siły transcendentalnej. Tu uwidacznia się paradoks niezrozumiały z punktu widzenia ludzkiej moralności.

Fragmentów zwiastujących nadchodzące nieszczęście jest w dramacie więcej, a w każdym z nich ironia święci kolejne triumfy. Już z na-

20 J. Cheryl Exum, Tragedy and Biblical Narrative. Arrows of the Almighty, Cambridge UP, Cambridge 1992, s. 9.

21 Por. N. Frye, Wielki kod. Biblia i literatura, przeł. A. Fulińska, Homini, Bydgoszcz 1998, s. 184-185.

22 Por. J. Cheryl Exum, op. cit., s. 10. 
stępującego po Prologu wróżebnego snu Storge, matki Ifis, wyłania się atmosfera narastającego zagrożenia mającego zawisnąć nad jej córką. Storge (jej imię w języku greckim oznacza miłość rodzicielska) dzieli się z Ifis niepokojącym przeczuciem wypływającym z alegorycznej wizji:

Widziałam idąc trzódę wilków srogich

Do stada owiec w pasterza ubogich,

Którym acz stróże własni zuciekali,

Pszedsię psi wierni targać ich nie dali.

Ażci zaś znowu k tej trzódzie lękliwej

$\mathrm{Z}$ chciwości owej srogiej, popędliwej,

Wilk się wróciwszy, owcę w łonie moim

Rozdarł drapieżnie ostrym zębem swoim.

(w. 97-107)

W utworze Buchanana sen bohaterki był świadomą aluzją do $\mathrm{He}$ kabe Eurypidesa ${ }^{23}$. W dziele tym królowa roztacza ponurą perspektywę przyszłych zdarzeń. Hekabe ujrzała bowiem, jak wilk porywa spod jej kolan cętkowaną łanię i dusi ją, bezbronną, szarpiąc za gardło. W onirycznym widzeniu pojawia się jeszcze duch Achillesa żądający daru jednej z Trojanek. Złowieszcze przesłanki łączą się w symboliczną jedność w bolejącej świadomości Hekabe: oto wilkiem jest Achilles domagający się ofiary z jej córki Polikseny, cały zaś sen to prefiguracja woli przeznaczenia. Tragiczne rozpoznanie wywołuje u kobiety pragnienie wyproszenia u bogów zmiany ich zamiarów względem życia dziecka ${ }^{24}$.

Jednakże w somnambulicznej wizji Storge $\mathrm{z}$ tragedii Buchanana zamiast zagrożenia zewnętrznego, jakim był wilk, pojawia się pies-obrońca:

23 Inspiracją mógł również być sen Andromachy z Troades Seneki.

24 Por. „Widziałam łanię pstrą w pazurach krwawych wilka / Duszoną, niemiłosiernie od kolan mych odciągniętą. / I tego jeszcze się lękam. Na samym szczycie mogiły / Zjawił się duch Achilla. Żądał zaś jako daru / Którejś z cierpiących Trojanek. / Od mojej, od mojej więc córki / Osuńcie to, bóstwa, błagam!" (Eurypides, Hekabe, w: Id., Tragedie, t. I, przeł. J. Łanowski, Prószyński i S-ka, Warszawa 2005 („Biblioteka Antyczna”), w. 90-97). Por. J. Czerwińska, Cztowiek Eurypidesa wobec zagrożenia życia, namiętności i ekstazy religijnej, Uniwersytet Łódzki, Łódź 1999, s. 34-35. 
Vidi luporum concito cursu gregem

Rictu cruento, spumeo, rabido, unguibus

Saevum recuruis praecipite ferri impetu

Imbellia, in pecora vidua pastoribus.

Tum pavidi ovilis fida custodia canis

Lupos abegit, atque ad infirmum pecus

Trepidi timoris examine adhuc memoria

Denuo reversus e sinu timidam meo

Agnam revulsam dente laniavit truci.

$$
\text { (w. 94-102) } 25
$$

To on, a nie wilki, uśmierca owieczkę. Odpędziwszy rozwścieczoną gromadę napastników pies pasterski zaczyna postępować zgodnie $\mathrm{z}$ instynktem i cechami przejętymi od dzikich krewnych. Porywając owieczkę i miażdżąc jej szyję na oczach matki staje się w istocie jednym z nich. Zachowanie psa u Buchanana może być odczytane jako symboliczna antycypacja działań Jeftego, który po odparciu wojsk ammonickich wraca do domu i stwarza tym samym największe zagrożenie dla ukochanego dziecka. Walczący w imię Boga przeciwko pogańskiemu plemieniu i jego krwawym zwyczajom ofiarniczym Jefte paradoksalnie sam upodabnia się do nieprzyjaciela pod względem barbarzyństwa, z jakim postępuje wobec własnego potomstwa ${ }^{26}$.

Odmienne w obu dramatach sposoby określania tożsamości Jeftego poprzez analogię do natury psa i wilka w istocie dopełniają się nawzajem. Z utworu Buchanana i Zawickiego wyłania się kompletna sylwetka niejednoznacznie ocenianego bohatera: jednocześnie psa i wilka, „swojego” i „obcego”, obrońcy i nieprzyjaciela, posiadającego instynkt opiekuńczy, lecz zdolnego go zdusić w pierwotnym odruchu zabijania.

25 Por. „Widziałam wilków wściekłych pędzące stado, / z otwartymi paszczami pełnymi piany i krwi, / srogimi pazurami atakujące z dziką furią / bezbronne owce, pozbawione pasterza. / Wówczas czujny i wierny pies / odpędził wilki od zalęknionego stada, / drżącego ze strachu wciąż jeszcze. / Wrócił ponownie i bojaźliwą owieczkę / rozszarpał zębem dzikim w piersi mojej”. Wszystkie cytaty z dzieła Buchanana pochodzą z edycji: Iephthes sive votum tragoedia, authore Georgio Buchanano Scoto, Lutetiae, Exofficina Michaëlis Vascosani, uia Iacobaea, ad insigne Fontis, M.D.LVII.

26 Por. H. Wolf, Judges, w: The Expositor's Bible Commentary, vol. 3, Zondervan, Grand Rapids 1992, s. 455; E. T. Mullen, The 'Minor Judges', w: Essays on Old Testament History and Religion, transl. R. A. Wilson, Garden City, New York 1968, s. 199. 
Obraz wilka w polskiej parafrazie zwraca uwagę nie tylko na te cechy bohatera, jakie ujawnią się w momencie ofiary (w. 1102-1103), lecz także nawiązuje do biblijnej sugestii na temat statusu Jeftego jako bękarta wypędzonego przez braci z domu rodzinnego i zdobywającego rozgłos dzięki wojowniczemu życiu w krainie Tob $(\mathrm{Sdz} 11,3)$.

W tekście łacińskim pies jest obrońcą swojej rodziny, lecz mimo to wciąż potomkiem wilczego stada. Jego zwycięska obrona przed niebezpieczeństwem grożącym domowemu ognisku, a następnie jego spustoszenie, mogą symbolizować powrót do dawnej natury. Motyw dziczejącego psa stanowi też, jak się zdaje, aluzję do politycznej degeneracji władcy, egzemplifikując tym samym drogę wiodącą od paradygmatycznego obrońcy ludu do wyniesionego ponad prawo krwawego tyrana. Według Mary Nyquist, Buchanan zapożyczył model takiej transformacji z dramatu Eurypidesa Herakles, w którym główny bohater po wielkich czynach dokonanych na polu bitwy wraca do domu i w obłędzie, z zimną krwią morduje swe potomstwo ${ }^{27}$. W słowach Ifis opisującej zachowanie powracającego z bitwy ojca pojawia się wizerunek srogiego, ponurego wodza, z wojennym grymasem na twarzy (w. 554-556).

Jeftes, nawet jako pies, nie jest częścią ochranianego stada; w grupie owiec staje się kimś obcym z racji niemożności nawiązania wewnątrzgatunkowych relacji. Pytanie o miejsce ojca w rodzinie przenosi się z planu fabularnego dramatu na plan teologiczny ukazujący problem relacji Boga i człowieka. Czy zza „wierzchniej szaty” snu Storge nie przebija podejrzenie, że Jefte to w istocie instrument bożego działania, ten, w którym Jahwe ujawnia się jako czynnik obcy, zagrażający domowej zagrodzie i etycznej stabilności ${ }^{28}$ Czy Jefte w tym śnie nie staje się figurą Boga?

A jednak znowu, jak na ironię, w planie realnym Jefte jest moralnie lepszy i nie tak zły, jak sugeruje Storge w swojej somnambulicznej wizji. U Buchanana Ifis przyznaje:

Hoc nemo nuper fuerat indulgentior

Nec liberorum quisquam amantior parens. ${ }^{29}$

(w. 550-553)

27 Por. M. Nyquist, The Plight of Buchanan's Jephtha: Sacrifice, Sovereignty, and Paternal Power, „Comparative Literature”, 2008, 60, s. 339.

28 Por. D. Kuller Shuger, op. cit., s. 145.

29 Por. „Nikt wcześniej nie był łagodniejszy, / ani też rodzic nie kochał bardziej żadnego z dzieci”. 
Zawicki przepełnionemu żalem ojcu każe wypowiedzieć słowa:

Ma dziecina niewinna w młodych leciech swoich

Karanie wziąć bezwinnie dla obietnic moich?

Mnie, mnie za własne głupstwo niech kaźń nagotują.

(w. 1202-1204)

Dowody człowieczeństwa Jeftego nie podlegają dyskusji, świadczą tylko, że jakaś siła naddana i wroga w sposób arbitralny nie dopuszcza możliwości, by skutki jego działań mogły być dobre, przeciwnie — zakłada apriorycznie ich tragiczny wymiar.

Skąd w głowie Storge wziął się profetyczny sen o takiej semantyce? Dla starożytnych sfera oneiromantyki tworzyła przestrzeń dla kontaktu z bogami (wyjawiali oni śniącym śmiertelnikom swoją wolę lub wskazywali przyszłość) ${ }^{30}$. W literaturze antycznej bogowie często korzystali z tego medium, jednak nie zawsze w sposób przychylny ludziom. W Iliadzie Homera Zeus zsyła na Agamemnona mamiący sen i nakazuje dowódcy Achajów, by ruszył na Troję, ponieważ nadszedł czas jej zdobycia. Agamemnon spełnia wolę boga i ponosi klęskę ${ }^{31}$. W Biblii sny, zwłaszcza profetyczne, są również boskiej proweniencji i, jak w przypadku Józefa, stanowią antycypację wydarzeń radosnych i bolesnych. Wymowna i weryfikowalna w bliskiej perspektywie wizja Storge nasuwa myśl o specyfice aktywności Boga, rozpościerającego w sferze ludzkiego snu horyzont przyszłych zdarzeń.

Mimo niepokojącej aury obecnej w planie zewnętrznym („wizyjnym"), akcja dramatu w planie zdarzeniowym rozgrywa się do pewnego momentu w sposób ciągły, zgodny z zamysłem głównego bohatera (podobnie jak w Biblii). W perspektywie ambicjonalnej Jefte osiągnął wszystko to, co chciał: ważną ze względów psychologicznych pozycję sędziego, a także gwarancję jej utrzymania przez długi czas w postaci odniesionego zwycięstwa. W wymiarze prowidencjalnym Duch Jahwe też zdaje się czuwać nad misją swego pomazańca i aktywnie ją wspierać, czego egzemplifikacją była klęska Ammonitów. W planie zdarzeniowym dostępnym percepcji bohatera należałoby oczekiwać zatem rozwiązania

30 Szerzej na ten temat zob. S. Oświęcimski, Zeus daje tylko znak, Apollo wieszczy osobiście, Ossolineum, Wrocław 1989.

31 Homer, Iliada, przeł. K. Jeżewska, wstęp i przypisy J. Łanowski, Prószyński i S-ka, Warszawa 1999, s. 41-43 (w. 1-84). 
akcji: oto Jefte pokonał wroga (peripeteia) i ukazał w swej osobie rzeczywistego wybawiciela (anagnorisis) ${ }^{32}$.

Tymczasem w niedostępnym dla bohatera planie zewnętrznym dramatu, w perspektywie nieszczęść zapowiadanych przez Anioła (pośrednio również przez Storge), kategorie te ulegają relatywizacji. Zdarzenia odwracają swój bieg (peripateia) w chwili, gdy, wbrew oczekiwaniom Jeftego, na spotkanie zwycięskiego ojca wychodzi jego córka. Od tego momentu tragiczna ironia ${ }^{33}$ przewartościowuje wszystkie wartości i wszystkie działania, które dokonały się za przyczyną Jeftego, on zaś, niczym Edyp, dostrzega całą prawdę. O ile jednak dla Edypa ujrzeć prawdę oznaczało „pozbawić się wzroku”, o tyle dla Jeftego poznanie prawdy symbolizowało odwrócenie głowy w inną stronę. Kiedy rozradowana Ifis wita swego ojca ${ }^{34}$, ten, bogatszy o zbyt późno rozpoznaną prawdę o swym losie (anagnorisis), wypowie ironiczne: „Niestetyż!” (w. 470). Do Jeftego, podobnie jak do Edypa, można więc odnieść słowa, że „staje się sam widzem swej tragedii, zewnętrznym świadkiem własnej świadomości” ${ }^{35}$. Edyp nie chce zabić swego ojca i poślubić matki; czyni to jednak przez wzgląd na nieznajomość ich tożsamości. Jefte nie zamierza poświęcić swojej córki; przysięga nie znając tożsamości tego, „Co wprzód zajdzie drógę” (w. 448). Podobnie jak u Sofoklesa, choć w mniejszym wymiarze, ironia staje się tragiczną kategorią epistemologiczną, służącą poznaniu ludzkiej egzystencji, uwikłanej w tajemne plany Transcendencji ${ }^{36}$. To, co dla Jeftego było jeszcze niedawno domeną niewiedzy, teraz staje się takie dla jego córki. Jakże ironiczny wydźwięk mają obecnie dla niego - bogatszego o tę wiedzę — słowa i zachowa-

32 Na możliwość analizy dramatu w oparciu o teorię tragedii Arystotelesa wskazuje J. H. McGregor (Id., The Sense of Tragedy in George Buchanan's „Jephthes”, „Humanistica Lovaniensia. Journal of Neo-Latin Studies”, 1992, 31, s. 124-128). Buchanan mógł albo sam czytać Poetykę, albo poznał ją pośrednio - poprzez lekturę tragedii greckich (zwłaszcza Eurypidesa). Zob. B. Weinberg, History of Literary Criticism in the Italian Renaissance, University of Chicago, Chicago 1961.

$33 \mathrm{O}$ związkach ironii z perypetią por. choćby P. Łaguna, Ironia jako postawa i jako wyraz (z zagadnień teoretycznych ironii), Wydawnictwo Literackie, Kraków 1984, s. 73.

34 Por. „Pójdę, azabym ojca mego obaczyła / Twarz wesołą, która mi po Bogu jest miła. / Na ramiona twe włożyć! Ale czemu swoje, / Ojcze, oczy odwracasz ode mnie uczciwe, / okazując wejrzeniem, iż są żałobliwe?” (w. 464-469).

35 W. Szturc, op. cit., s. 9.

36 Por. ibidem, s. 15. 
nie nieświadomej swego losu Ifis, która najpierw sama obarcza się winą za smutek ojca (w. 481), a po usłyszeniu z kolei ojcowskiego samooskarżenia: „tobiem ja sam zgrzeszył wiele” (w. 482) stwierdza z dziecięcą dobrodusznością:

Mnieś namniej nie przegniewał, mogę przysiąc śmiele.

I tak mniemam, że taki frasunek jest próżny

(Krzywdy się mścić) w rodzicach, i namniej niedrożny.

Znosić skromnie przystoi krzywdę starszych swoich.

(w. 483-486)

Niewiedza dziewczyny osiąga swe apogeum w psalmistycznej aklamacji:

Kiedy łaskawe szczęście po swej woli znamy,

Natenczas przez modlitwy Boga wzywać mamy,

Nie — kiedy nam żałosne szczęście wiatry swemi

Portu nie da dostępić, bywać nabożnemi.

Bo który w szczęśliwy czas nie opuszcza Boga,

Nie wzruszy go w nieszczęściu by nacięższa trwoga.

(w. 504-509)

Tragiczna ironia wyraża się w koincydencji ślubu Jeftego i następujących po nim wydarzeń. Jefte ślubował, że złoży w ofierze dziękczynnej istotę, która jako pierwsza wyjdzie mu na spotkanie po walce z Ammonitami (w. 444-447). Dlaczego jednak na spotkanie wyszła jego córka, a nie ktoś lub coś innego? Czy można fakt ten wytłumaczyć dziełem przypadku, czy może kryje się za nim coś, co James Joyce określił kiedyś mianem „tajemniczej przyczyny cierpienia” („secret cause of suffering”) ${ }^{37}$ ? Arystoteles z kolei w swojej Poetyce pisał: „nawet spośród zdarzeń przypadkowych te wydają się najbardziej zaskakujące, które sprawiają wrażenie zamierzonych [...]. Ludziom wydaje się przecież, że takie rzeczy nie dzieją się przypadkowo" ${ }^{38}$. Mogłoby więc znaczyć, iż cierpienie Jeftego wyrażone w renesansowej tragedii nie musi być rozpatrywane wyłącznie w kategoriach jego winy, ponieważ „coš” niepoko-

37 Por. R. B. Sewall, The Vision of Tragedy, Yale UP, New Haven 1980, s. 7.

38 Arystoteles, Poetyka, przeł. i oprac. H. Podbielski, Ossolineum, Wrocław 1983, s. 20 . 
jącego i nie do końca nazwanego leży gdzieś poza nim. Teza ta potwierdza się zwłaszcza pod wpływem proroczej zapowiedzi Anioła w planie zewnętrznym dramatu ${ }^{39}$ : triumf wojenny będzie znakiem przychylnej fortuny, ślub natomiast — antycypacją tragedii:

Porro ne Iephthes quoque

Se metiatur exitu huius proelii

Et intumescat insolens rebus bonis,

Damno obruetur protinus domestico,

Cedentque fracti contumaces spiritus. [...]

Heu, quanta moles imminet tibi mali,

Miserande! quantis obruere luctibus! ${ }^{40}$

(w. 51-55, 60-61)

W momencie największej chwały Jeftego tkwi już więc zarodek tragedii, wiktoria nad Ammonitami okazuje się triumfem ironii, gdyż akt ślubu przeradza ją w Pyrrusowe zwycięstwo ${ }^{41}$. Jakże gorzko dla przepełnionego bólem wodza muszą brzmieć teraz słowa jego przyjaciela Symachusa ${ }^{42}$ :

Tobie jest wszystko z mocy Bożej dano [...]

Sława uczciwa, zwycięstwo ozdobne;

Żeś w łasce Pańskiej, masz znaki podobne.

(w. 615-617)

$39 \mathrm{Na}$ uwagę zasługuje fakt, że niektórzy egzegeci nieszczęsne rozpoznanie Jeftego interpretują w kategoriach bożej kary za bezbożny i bezmyślny ślub.

40 Por. „By jednak Jefte / nie przeceniał swych zasług wojennych / i nie wynosił się, zarozumiały, z powodu sukcesów, / nieszczęściem domowym będzie przygnieciony, / jego uparty duch złamie się i ustąpi. / [...] / "Ach, jaki ogrom zła czyha na ciebie, / nędzniku! przytłoczony cierpieniem»".

41 O tragicznej ironii por. A. Doda, Ironia i ofiara, UAM, Poznań 2007, s. 49.

42 Fenomen ten w pełni oddają słowa Maxa Schelera: „[...] gdzie bezpośrednio przeżywamy działalność, która realizując wysoką wartość, równocześnie i w tym samym akcie działania podkopuje warunek jej istnienia lub też innej z nią związanej wartości, tam wrażenie tragiczności jest najpełniejsze i najczystsze" (Arystoteles, D. Hume, M. Scheler, O tragedii i tragiczności, przeł. R. Ingarden, wybór, przedm. i oprac. W. Tatarkiewiczowa, Wydawnictwo Literackie, Kraków 1976, s. 70-71). 
Fatalna obietnica, co warto podkreślić, dokonała się nie tylko w ramach realizacji woli bożej ewokowanej w Prologu, lecz również w czasie, gdy nad Jeftem i jego sprawą unosił się Duch Boży, o czym informuje Biblia (Sdz 11, 29) ${ }^{43} \mathrm{i}$ - pośrednio - Poseł, mówiąc: „Wszystko święta prawica Jego rozproszyła” (w. 304). W takim kontekście sam charakter ślubu Jeftego ulega niepokojącej relatywizacji, wskazując na immanentną zależność pomiędzy aktem człowieka a ingerencją siły transcendentalnej. Już imię bohatera 'yiptaḥ', znaczące „on otwiera” i nawiązujące w istocie do wyrażenia 'yiptah 'ēl' — „Bóg otwiera”44, odsłania w dramacie swój głęboko tragiczny wymiar łączący się z semantyką Bożego działania, które przez to jakby podważa autonomię czynów noszącego je człowieka.

W ujęciu biblijnym przedmiotem takiej działalności Boga miałoby być w pierwszej kolejności łono brzemiennej kobiety, z którego Stwórca „wydobywa” dziecię na świat (Rdz 29, 31; 30, 22). Księga Sędziów rejestruje jednak zaburzenie powyższego schematu: Jefte „otwierając swoje usta" do ślubu odwraca życiodajny czyn Boga. Niektórzy teologowie widzą w warunkowym akcie Jeftego („Jeśli dasz...”; Sdz 11,30) rodzaj transakcji z Bogiem wynikającej z troski o własne powodzenie ${ }^{45}$.

Tymczasem w dramacie Buchanana - Zawickiego ślub nabiera dodatkowych znaczeń. Podobnie jak w Biblii mamy tu ironiczną grę słów związaną z czynem Jeftego: zamiast dawać życie jak Bóg (otwierający kobiece łono), otwiera on usta do przysięgi skutkującej śmiercią dziecka. Okazuje się jednocześnie, że w odniesieniu do tej gry słów tajemnicza wizja Storge zyskuje swą eksplikację w fatalnej obietnicy Jeftego, który jak „wilk się wróciwszy, owcę w łonie moim / Rozdarł drapieżnie ostrym zębem swoim” (w. 106-107). W kumulacji znaczeń „ostry ząb” Jeftego staje się, niczym biblijny „miecz obosieczny” ( $\mathrm{Hbr} 4$, 12; Prz 5, 3-4), synonimem szczególnej mocy słowa posiadającej realny wpływ na kreowaną przez siebie rzeczywistość. W tym sensie Jefte po odparciu wroga zewnętrznego i powrocie do domu staje się dla niego, poprzez własne słowo, jeszcze większym, wewnętrznym zagrożeniem.

43 „Factus est ergo super Iephte Spiritus Domini, \& circuiens Galaad \& Manasse, Maspha quoque Galaad, \& inde transiens ad filios Ammon”, k. 70 („A tak stał się nad Jephtem Duch Pański, a obchodząc Galaad y Manasse, Maspha też Galaad, a stamtąd ciągnąc do synów Ammon", s. 254).

44 Por. J. Cheryl Exum, op. cit., s. 48.

45 Por. W. Pikor, Jefte - paradygmat niespetnionego wtadcy (Sdz 10,6-12,7), „Roczniki Teologiczne", 2006, 53, z. 1, s. 35-57. 
Czy jednak taka interpretacja w dostateczny sposób tłumaczy istotę tragizmu Jeftego zawartą $\mathrm{w}$ dramacie Buchanana - Zawickiego? W świetle proroczych słów Anioła (w. 61-66), uzupełnionych alegoryczną wizją Storge, imię bohatera zyskuje nową, ludzko-boską, tragicznie ironiczną wykładnię: „On (Bóg) otwiera łono” / „on (Jefte) otwiera swe usta”, która umożliwia „tragiczne” odczytanie: „On (Bóg) otwiera (Jeftego) usta".

Jeśli tak jest w istocie, to „wina” staje się pojęciem relatywnym i niejednoznacznym, w którym Bóg wcale nie znika z horyzontu podejrzeń, mimo apologetycznych zapewnień płynących ze strony Kapłana i Symachusa pouczających, że „Ani też mamy Bogu złych spraw przypisować" (w. 853), ani nie powinniśmy posądzać Go o akceptację krwawych ofiar:

Sac. Deus

Ut rite sacris gaudet oblatis, ita

Nefanda vota respuit nec abstulit

Impune, quamvis concitus studio pio,

Admovit ignem qui profanum altaribus.

Igitur amica monita ne sperne, et deum

Placare dum vis, concitare desine,

Non instituto qui coli gaudet tuo,

Sed sibi probatis lege, ritu, moribus. ${ }^{46}$

$$
\text { (w. 954-962) }
$$

Nawet w replikach Chóru, obok ogólnego przeświadczenia o dobroci Boga (w. 310-313), pojawia się niepokojąca myśl o nieznanym, groźnym dla człowieka obliczu Jahwe (w. 1030-1035).

Kto zatem powinien ponieść karę? Odpowiedź być może ukryta jest w teologicznym dyskursie Jeftego z przyjacielem Symachusem i Kapłanem (Sacerdos) próbującymi odwieść bohatera od bezbożnej ofiary. Jeftego w dramatach Buchanana i Zawickiego nie przekonują żadne argumenty (bohater widzi w nich tylko uczoną sofistykę): ani prawo

46 Por. „Jak słusznie raduje się Bóg ze świętych rytów ofiarnych, / tak bezbożne śluby odrzuca, i nie ujdzie / bezkarnie kto, mimo gorliwej pobożności, / pali bezbożny ogień na ołtarzach. / Przyjacielskiego napomnienia zatem nie odrzucaj. / Bóg wybaczy, gdy przemocy odstąpisz. / Nie ma On upodobania w twoim czynie, / lecz w prawie, obrzędzie i zwyczaju, które sam zatwierdził”. 
boskie, potępiające akt rytualnego zabójstwa i zabraniające składania obietnic sprzecznych z wolą Boga, ani prawo natury, odwołujące się do miłości rodzicielskiej Boga wobec Jego stworzeń (w. 840-862). Odpowiadając Symachusowi i Kapłanowi, Jefte, nawiązując do słów św. Pawła $(1$ Kor 1, 25), stwierdza: „Wy tak chodźcie, wodzowie wszelakich mądrości; / Ja wolę prawdę głupią niż waszych chytrości / Naszladować” (w. 979-981). Kiedy odnosi się do pytania o status człowieka zabijającego własne dziecię, przypomina zaś ofiarę Abrahama: „Mactare natum iussit Abramum Deus" (w. 920).

W kontekście ofiary Abrahama sytuacja sędziego nabiera ironicznego wydźwięku. Zapewnienie nieświadomego niczego Izaaka, że „Bóg upatrzy sobie jagnię na całopalenie” ( $\mathrm{Rdz} 22,8)$, kontrastuje z niewiedzą i dramatem poznania Jeftego, który w witającej go córce dostrzega przedmiot swojego ślubu (w. 470). Ponadto, o ile w przypadku Abrahama Izaak (zastąpiony ostatecznie przez baranka) stał się świadectwem autentyczności obietnicy niezliczonego potomstwa, jakim Bóg go obdarzy (Rdz 17, 2-6), o tyle dla Jeftego bezpotomna śmierć Ifis oznaczała kres nadziei na przedłużenie rodu (w. 1038-1039) ${ }^{47}$.

Dialog Kapłana i Jeftego odsłania w istocie problem relacji rozumu i wiary, tego, co oświecone i tego, co ginie w „ciemnościach misterium”, Boga objawionego ludzkiemu umysłowi i Boga utożsamionego z losem ${ }^{48}$. Paradoksalnie Jefte wie, że swą decyzją przekroczył prawo i że poniesie jej konsekwencje (w. 736-741). Z góry więc zakłada nieodwracalny charakter własnego postanowienia. Z czego zatem wynika „tragiczna w swym zamknięciu na racjonalność wiara Jeftego”, przeciwstawiająca się wszystkiemu, co wypływa z nakazu „Prawa objawionemu rozumowi"? ${ }^{49}$ Czy Jefte jest aż tak posłuszny Bogu? Czy też może jego upór jest wynikiem błędnego mniemania lub szaleństwa? A może jest jakiś inny powód?

Dramat Buchanana - Zawickiego przedstawia tragedię człowieka, który własną lekkomyślnością i uporczywym trwaniem w błędzie sprowadza nieszczęście na siebie i bliskich. Przyznaje to sam bohater i już nawet gotów jest ponieść konsekwencje „głupiej” obietnicy:

47 Zob. M. J. Smith, The Failure of the Family in Judges, Part 1: Jephthah, „Bibliotheca Sacra”, 2005, 162, s. 295.

48 Por. M. Hanusiewicz-Lavalle, Tragedia rozumu i pobożności. „Iephthes” Buchanana-Zawickiego, OiRwP, 2008, 52, s. 39-49.

49 Ibidem, s. 41. 
Mnie, mnie za własne głupstwo niech kaźń nagotują,

A zazdrośni sąsiedzi niech mnie nie winują,

Abym ja meżobójcą miał być dziatek swoich!

(w. 1204-1206)

Wcześniej powie jeszcze, że człowiek o zdrowych zmysłach nie mógłby złożyć bezbożnego ślubu: „Nemo ista sanus vota nuncupauerit” (w. 915). Wygląda więc na to, że „w wersji Buchanana i Zawickiego Bóg zostaje całkowicie wyłączony z odpowiedzialności za ślub Jeftego, nie bierze udziału w 'realizacji umowy', gdyż ofiara Jeftego ma być ofiarą dziękczynną" ${ }^{\circ}$. Prawda ta wynika ze stwierdzeń Kapłana, Symachusa, Storge i jest całkowicie weryfikowalna w planie wewnętrznym utworu (teodycea). A jednak kiedy naprzeciw nieszczęściu ojca wychodzi Ifis z dobrowolnym aktem ekspiacji, wyraźnie daje do zrozumienia, że jego ślub wcale nie był wynikiem suwerennej decyzji, lecz dziełem nieubłaganej konieczności:

Quod non volentem dura te necessitas

Isthuc coegit, multa mihi faciunt fidem:

Moestitia praesens, pristina indulgentia,

Et nullius mens criminis mihi conscia,

Cur commereri debeam mortem a patre.

Quapropter istud quicquid est necessitas

Quod cogit, ultro non recuso perpeti,

Et quam parenti patriaequae debeo

Animam libenter reddo. ${ }^{51}$

(w. 1261-1269)

W kontekście słów Anioła zawartych w Prologu, że nieszczęście Jeftego jest nauką Boga chroniącą bohatera przed nadmierną pychą, podejrzenia córki bohatera stają się jeszcze bardziej prawdopodobne. Każą bowiem widzieć czyny ojca i jej własne w perspektywie uwikłania

$50 \quad$ Ibidem, s. 39.

51 „Że — tak niechętnego — sroga konieczność / ciebie przymusiła, wiele rzeczy mnie przekonuje: / obecny smutek, dawna łagodność, / i mój umysł nieświadomy winy, / czemu miałabym zasłużyć na śmierć z ręki ojca. / Dlatego cokolwiek, do czego zmusza konieczność, / dobrowolnie, bez sprzeciwu wykonam, / i życie, które ojcu i ojczyźnie jestem winna, / chętnie oddam”. 
w zewnętrzny plan boskiej konieczności (necessitas, praedestinatio). Potencjalna obecność pierwiastków kalwińskich w dramacie Buchanana mogłaby się tłumaczyć protestanckimi sympatiami autora, który tworzył swe dzieło jeszcze jako katolik, ale już kilka lat po jego napisaniu opowiedział się oficjalnie po stronie Kościoła reformowanego ${ }^{52}$. Należy jednocześnie pamiętać, że poeta do samego końca pozostał humanistą spod znaku Erazma i że „w gruncie rzeczy [był] jednakowo odległy od instytucjonalnie i doktrynalnie określonego katolicyzmu i kalwinizmu" 53 .

Pytanie o granice wolności człowieka w konfrontacji z Bogiem jest jednym z podstawowych, jakie stawia omawiany utwór. W inspirowanej mitologią tragedii greckiej wola człowieka podporządkowana była woli bogów, sterowana planami Mojry ${ }^{54}$; w Biblii człowiek posiadał autonomię, mógł w sposób suwerenny wybierać pomiędzy dobrem i złem, lecz ponosił konsekwencje swych czynów, będących przecież częścią niezmiennych planów bożych ${ }^{55}$. Chociaż w przekonaniu Jeftego ślub zaistniał na mocy jego dobrowolnej decyzji, to jednak zachowuje się tak, jakby realizował plan przeznaczenia ${ }^{56}$. Jego postępowania nie zmieni już nic (ani argumenty Symachusa, Kapłana i Storge, ani nawet własna świadomość błędu). Postrzegane jako niezrozumiałe zachowanie Jeftego (w planie wewnętrznym dramatu) staje się w istocie częścią niezmiennych planów Boga (Prolog), które muszą się spełnić (w. 61-66).

Jakby przeczuwając tę prawdę, Jefte dobrowolnie i pokornie przyjmuje swój los. W przeciwieństwie do Edypa czy Saula, którzy aktywnie przeciwstawiają się woli sił wyższych, nie toczy on walki z Transcendencją. Dlatego z tej perspektywy nie jest on bohaterem tragicznym, startym na proch $\mathrm{w}$ walce $\mathrm{z}$ nierównym przeciwnikiem. Jeftem nie kieruje pycha (hybris), jaka towarzyszyła racjonalnemu wysiłkowi Edypa próbującemu poznać prawdę. Wyzuty z niej zupełnie ze spokojem

52 Por. A. Budzisz, Biblia i tradycja antyczna. Motywy analogiczne w tacińskiej poezji biblijnej renesansu (Polska, Niemcy, Niderlandy, Wyspy Brytyjskie), KUL, Lublin 1995, s. 88-89; J. Abramowska, op. cit., s. 78.

53 M. Hanusiewicz-Lavalle, op. cit., s. 49.

54 Por. A. Krokiewicz, Moralność Homera i etyka Hezjoda, PAX, Warszawa 1959, s. 74-96.

55 Por. A. Budzisz, op. cit., s. 91.

56 Inaczej jest z Agamemnonem w tragedii Eurypidesa Ifgenia w Aulidzie. Od wodza ofiary z córki zażądała obrażona Artemida, która, jak sądzi Agamemnon, nie działała dobrowolnie, lecz pod przymusem Przeznaczenia. 
i pokorą znosi los, ponosząc w ten sposób konsekwencje zbłądzenia (hamartia), choć do końca nie jest za nie odpowiedzialny. A im trudniejsze ma zadanie, tym więcej heroizmu wkłada, by doprowadzić swoje dzieło do końca. Przeciwstawia się jedynie tym, którzy chcą skłonić go do naprawienia błędu i całkowicie odrzuca możliwość skorzystania z konformistycznych wykładni Prawa Mojżeszowego, jakie proponuje mu Kapłan. Mimo pewnej analogii do historii Edypa, postawa Jeftego wobec losu różni się od tej charakterystycznej dla bohatera tragedii Sofoklesa. Określa ją nie logika rozumu (nie można jej jednak całkowicie odmówić Jeftemu), lecz logika żołnierskiej subordynacji i honoru, którą Jefte przenosi także w sferę pobożności. Ona każe mu pozostać przy raz danym słowie, mimo racji rozumu i mimo przygniatającej świadomości, że w obliczu tajemniczego milczenia Jahwe, który nie zsyła baranka jak Abrahamowi, trzeba będzie wybrać rozwiązanie najtrudniejsze ze wszystkich. Jefte wie, iż ofiarą przebłagalną za jego winę będzie Ifis: nie walczy ona z decyzją ojca, ale dobrowolnie przyjmuje swój los ${ }^{57}$.

Z drugiej strony, poprzez swą uległość Jefte sam jak gdyby wchodzi w rolę zwierzęcia ofiarnego. W perspektywie proroczych słów anielskich staje się kimś w rodzaju „niewinnego grzesznika”: bez buntu uzna on winę, do której popełnienia popchnął go Bóg, ponieważ aktem bezbożnej ofiary wypełnia jedynie to, co i tak musi się stać. Janina Abramowska powie, że „odpowiedzialność za zbrodnię musi ponosić człowiek albo Bóg. Skoro Bóg winien być nie może, człowiek musi ją wziąć na siebie" 58 . Przywołuje w tym miejscu koncepcję Rolanda Barthesa. Jego zdaniem, tragizm $\mathrm{w}$ tragedii chrześcijańskiej wynikał $\mathrm{z}$ wzięcia przez człowieka na siebie „winy” Boga w ramach tzw. „odwróconej” soteriologii. Skoro na horyzoncie podejrzeń nie zabrakło Boga z Jego ponurym wyrokiem, jaki zapadł w przedakcji dramatu, całkowitym Jego milczeniem towarzyszącym obietnicy i ofierze swego sługi, to może Jefte „jak każdy bohater tragiczny rodzi się niewinny: zostaje winowajcą, aby ratować Boga" ${ }^{2}$.

57 Zob. N. Woolff, Shakespeare's Tragic Family: Sacrificers and Victims from Cain to Hamlet, University of Manitoba, Winnipeg - Manitoba 1998, s. 25-35. O sensie chrystologicznym ofiary córki Jeftego por. M. Ephraim, Reading the Jewish Woman on the Elizabethan Stage, Ashgate, Hampshire 2008, s. 89-112.

58 J. Abramowska, op. cit., s. 77.

59 R. Barthes, Człowiek Racine’a. Struktura, przeł. W. Błońska, w: Id., Mit i znak. Eseje, PIW, Warszawa 1970, s. 145. 
Problem niejednoznaczności winy zbliża Jephtesa do filozofii Ricoeura, w której pojawia się refleksja dotycząca zła podstaw ow ego łączącego się z zagadnieniem tragicznej antropologii i teologii. Jego zdaniem, „teologia tragiczna jest zawsze możliwa, chociaż nigdy nie daje się wypowiedzieć; Bóg to Deus absconditus; a jest ona zawsze możliwa, ponieważ cierpienie nie może być już rozumiane jako kara" ${ }^{60}$.

Istotną rolę w dotarciu do przyczyn tragedii Jeftego mogą pełnić w dramacie pieśni chóru. Wielokrotnie przewija się w nich motyw antycznej Fortuny i chrześcijańskiej Opatrzności. Wśród utworów głoszących chwałę Bożej mocy, sprawiedliwości i wszechwiedzy (pieśni I-IV) szczególne miejsce zajmuje pieśń piąta. W niej bowiem czytamy:

Pan Bóg na wspak rzeczy człowiecze obraca,

Jako znikomy wicher swym pędem wywraca.

(w. 1030-1031)

Znamienne, gdyż wcześniej takie działanie było domeną Fortuny zawierającej w sobie pojęcie ironii wrogiego człowiekowi losu ${ }^{61}$ :

Na co dziś, baczę, złe szczęście chciwe

Targa się swoim nieobronionym

Pędem. A ciebie widząc zgwałconym,

Twój nieprzyjaciel na złość się śmieje

I szydząc z ciebie, głową swą chwieje [...].

(w. 996-1000)

Obdarzona ironicznym i „prześmiewczym” charakterem Fortuna upodabniała się nawet do szatana szydzącego z karkołomnych poczynań bohatera. Człowiek nigdy nie wie, „co mu da szczęście, czego go zbawi” (w. 990), widzi jedynie, że, podobnie jak w Pieśni II, 9 Jana Kochanowskiego: „Fortuna w żywe oczy szydzi: / To da, to weźmie, jako się jej wi-

60 P. Ricoeur, Symbolika zta, przeł. S. Cichowicz, M. Ochab, De Agostini - Altaya, Warszawa 2002, s. 383.

${ }_{61}$ Por. D. S. Muecke, Ironia: podstawowe klasyfikacje, PL, 1986, t. 77, z. 1, s. 250 251; R. Koschany, Ironia losu ( $w$ sztukach fabularnych), w: Powaga ironii, red. A. Doda, Toruń 2004, s. 289-300. 
dzi” (w. 23-24) ${ }^{62}$. Symachus w rozmowie z Jeftem odniesie się do jego ślepego trwania przy zamiarze wypełnienia ślubu w następujący sposób:

Sława jest moja, żem ci dobrze radził;

Że tak nie padło, wróg jakiś zawadził.

Skutek ma w ręku szczęście wszystkich rzeczy.

(w. 756-758)

Wielokrotnie powtarzany $\mathrm{w}$ dramacie wątek błędu i zaślepienia Jeftego znajduje i teraz swą artykulację:

A ty twarz twoję umywasz łzami,

Nędzniku, z twemi obietnicami!

Czarna mgła błędu cię zaślepiła,

A światła widzieć nie dopuściła.

Po krzywych skałach dziwnie cię wodzi,

Gdzie noga twoja nieraz ugodzi

$\mathrm{Na}$ ostry kamień błędu śliskiego

Tak tu nic człowiek nie ma pewnego.

(w. 1001-1008)

Wygląda na to, że Fortuna lub jakaś nieokreślona do końca moc kosmiczna (u Zawickiego kilka razy pada określenie „wróg”, mogące sugerować szatana) ${ }^{63}$ kieruje na bezdroża kroki bohatera. Już w pieśni czwartej chór ubolewał nad losem Jeftego:

Któremu srogi błąd swe okowy

$\mathrm{Na}$ nogi włożył, a rozum zdrowy

Odjąwszy, radzi, aby niezbożne

Uczynki swoje udał za drożne.

(w. 766-769)

Powstaje pytanie, czy Fortuna, utrudniająca właściwą ocenę rzeczywistości i odbierająca człowiekowi wolność kształtowania jego losu, nie

62 J. Kochanowski, Pieśni, oprac. L. Szczerbicka-Ślęk, Ossolineum, Wrocław 2005, s. 80 .

${ }^{63}$ Zob. J. Bedyniak, Opatrzność i wróg. O Janie Zawickim i jego tragedii "Jeftes", OiRwP, 2011, 55, s. 80-84. 
staje się symbolem „hostile transcendence” i „arbitrary fate”? Może, jak w przypadku tragicznych losów Saula, mamy w dramacie do czynienia $\mathrm{z}$ ambiwalentną rolą Boga ${ }^{64}$, który najpierw wywyższa, a następnie przyczynia się do upadku swego sługi i staje się jego „wrogiem” (1 Sm 28, 16), by ostatecznie doprowadzić go do szaleństwa? Mroki błędu, które ogarnęły Jeftego, mogą zyskać jeszcze pełniejszą wykładnię, kiedy zestawi się je z początkowymi słowami Anioła ogłaszającego niezmienne wyroki Jahwe. Wówczas pojawiałby się paradoks ludzkiej winy i wrogiej transcendencji ${ }^{65}$. Saul, mimo swych owocnych i sprawiedliwych rządów, jak na ówczesne standardy, dowiaduje się za sprawą Samuela, że Bóg go odrzucił (1 Sm 28, 16). Dla Jeftego plany boże pozostają tajemnicą. Realizuje je jednak niezłomnie, w sposób fanatyczny, aż do ostatecznego wypełnienia.

Zagadka istnienia czynnika nadprzyrodzonego odpowiedzialnego za zło dotykające człowieka w ujęciu chrześcijańskim wyjaśnia się naturalnie w ogrodzie Eden, gdzie do głosu dochodzi antynomiczna wizja dobrego Boga i złego szatana. Aposterioryczne przeświadczenie o bożej dobroci, widoczne w dziele stworzenia ex nihilo, wyłącza Boga z obszaru odpowiedzialności za zło, umacniając tym samym koncepcję teodycei. Dlatego kwestia atrybucji zła w perspektywie judeochrześcijańskiej jest oczywista: źródłem malum jest szatan, względnie człowiek podatny na jego sugestie. Co jednak zrobić w sytuacji, gdy granica ta ulega zatarciu, a nieprzyjacielem zdaje się Bóg? Czy dostatecznym wyjaśnieniem będzie stwierdzenie, że Bóg tylko dopuszcza istnienie zła po to, by pomnożyć dobro?

Możliwość zaistnienia tragizmu, czy też — w węższym zakresie tragediii ${ }^{66}$, staje się realna w momencie, gdy ludzka wolność w niewyjaśniony sposób znajdzie się wobec siły kosmicznej, transcendentalnej, która zechce tę wolność w jakiś (sobie tylko znany) sposób ograniczyć, utrzymując jednocześnie pozór jej autonomii w świadomości człowieka. Pytanie, które rodzi się na gruncie tak postawionej tezy, dotyka jednocześnie fenomenu wolności i zła oraz wolności i przeznaczenia w ujęciu dialektycznym, obecnym zarówno w tradycji antycznej, jak i tradycji biblijnej. Z jednej bowiem strony rozpatruje winę etyczną popełnioną

${ }^{64}$ Por. J. Cheryl Exum, op. cit., s. 16-18. Zob. też E. M. Good, Irony in the Old Testament, Westminster Press, Philadelphia 1965.

65 Por. P. Ricoeur, Symbolika zta, s. 262-263.

66 Por. J. Tischner, Filozofia dramatu, Znak, Kraków 2006, s. 47. 
przez człowieka („Unde malum faciamus?”), z drugiej poszukuje czynnika metafizycznego („Unde malum?”), który mógłby tę winę w jakiś sposób sankcjonować lub też usprawiedliwiać.

Historia Jeftego wykorzystana przez Buchanana i Zawickiego w duchu dialogu kultury antycznej i tradycji chrześcijańskiej prowokuje do wyrażenia wielu wątpliwości. Niektórych z nich (w tym podstawowych dotyczących przeznaczenia i wolności, winy i kary, Boga i człowieka) pisarze (szczególnie Buchanan) nie wyjaśniają, pozostawiając je w ambiwalentnym napięciu. Może rzeczywiście jest tak, jak twierdzi Ricoeur: „Widziałem wyraźnie, że symbolika zła, której ilustracją są tragedia grecka, mity i opowieści biblijne, nie pokrywa całego obszaru winy i że jest tu coś więcej" ${ }^{67}$ ?

\section{The Irony, Tragedy and Mystery of God in the Biblical Drama Jephthes by George Buchanan — Jan Zawicki}

The article refers to one of the most famous 16th century humanistic dramas, the biblical tragedy Jephthes sive votum, written by Scottish humanist George Buchanan (1554), which was translated into Polish by Jan Zawicki and published in 1587. The central plot is based on an Old Testament story, contained in the Book of Judges, about one Jephthe who had sacrificed his daughter to God (Judges 11, 29-40). According to the renaissance principle of substitution, the biblical passage was incorporated into the scheme of Eurypidian tragedy Ifigeneia in Aulis. By the same method, Buchanan created the first modern tragedy with overtones of religion. The heart of Jephtah's tragedy may be located in the paradox of human guilt and the inconceivable judgement of God. Jephtah is guilty, he opens his mouth to the vow, but he is not really wicked. Unlike the Angel's statement in the prologue of the play, he lacks hubris, his words and deeds illustrate his piety and confidence in Yahweh. Ironically, Jephtah's piety accelerates his disaster, and his virtue comes into hamartia. Therefore his "guilt" becomes particularly ambiguous, and remains in the shadow of the mysterious silence of God.

67 P. Ricoeur, Krytyka i przekonanie, przeł. M. Drwięga, Wydawnictwo KR, Warszawa 2003 , s. 46. 